Vol. V No. 1, Des 2018, hlm. 37 - 42

DOI: https://doi.org/10.33330/jurteksi.v5i1.295

Available online at http://jurnal.stmikroyal.ac.id/index.php/jurteksi

\title{
ANALISIS DAN PERANCANGAN WEBBASE DAN WAP TICKET CENTER RESERVATION PADA PO. NPM DENGAN METODE PROSEDUR MULTI USER
}

\author{
${ }^{1}$ Agus Suryadi, ${ }^{2}$ Mahardika Abdi Prawira Tanjung ${ }^{3}$ Eka Lia Febrianti \\ Program Studi Sistem Informasi, Program Studi Sistem Komputer, \\ STMIK Royal Kisaran \\ e-mail: ${ }^{1}$ agussuryadi@ royal.ac.id ${ }^{2}$ dika.abdi@gmail.com ${ }^{3}$ ekalia88@gmail.com
}

\begin{abstract}
In this growing era of globalization, information systems are very important and important in helping business processes, in the near future that will make the competition in the business process will be more violent and strict. Therefore, the use of information technology and the design of application programming using PHP as server side programing and MySQ1 as its database especially regarding bus departure and bus ticket reservation at PO.NPM company of bukittinggi city. Problems faced by this company is the problem of data redundancy ticket booking is a lot of data booking tickets are not available, and not presented in sequence and repeatedly resulting in difficulties when manipulating, altering, and delete data. In the end the authors hope with the creation of a new information system, can help the process of booking tickets and done more easily, without the passengers concerned must come directly to P0.NPM with the new system design will facilitate the company and bus visitors.
\end{abstract}

Keywords: Technology, Information, PHP Programming Language And MySQL.

\begin{abstract}
Abstrak : Di era globalisasi yang semakin berkembang ini sistem informasi merupakan hal yang sangat penting dan utama dalam membantu proses bisnis, dalam waktu dekat yang akan membuat persaingan dalam proses bisnis akan semakin keras dan ketat. Karena itu pemakaian teknologi informasi dan rancangan pembuatan program aplikasi dengan menggunakan PHP sebagai server side programing dan MySQ1 sebagai Databasenya khususnya mengenai jadwal keberangkatan bus dan pemesanan tiket bus pada perusahaan PO.NPM kota bukittinggi. Masalah - masalah yang dihadapi perusahaan ini yaitu masalah redundansi data pemesanan tiket yaitu banyak data pemesanan tiket yang tidak tersedia,dan tidak tersaji secara berurutan dan berulang-ulang sehingga mengakibatkan kesulitan saat memanipulasi, mengubah, dan menghapus data. Pada akhirnya penulis berharap dengan dibuatnya sistem informasi yang baru, dapat membantu Proses pemesanan tiket dan dilakukan dengan lebih mudah, tanpa penumpang yang bersangkutan harus datang langsung ke P0.NPM dengan adanya desain sistem yang baru akan mempermudah pihak perusahaan dan pengunjung bus.
\end{abstract}

Kata kunci : Teknologi, Informasi, Bahasa Pemograman PHP Dan MySQL.

\section{PENDAHULUAN}

Di era globalisasi yang semakin ber-kembang ini sistem informasi merupakan hal yang sangat penting dan utama dalam membantu proses bisnis, dalam waktu dekat yang akan membuat persaingan dalam proses bisnis akan semakin keras dan ketat [1]. Karena itu pemakaian teknologi Informasi dalam berbagai aspek kehidupan telah berevolusi dan banyak mengalami perkembangan [2]. 
Masalah - masalah yang dihadapi perusahaan ini yaitu masalah redundansi data pemesanan tiket yaitu banyak data pemesanan tiket yang tersedia tersaji secara tidak berurutan dan berulang-ulang sehingga mengakibatkan kesulitan saat memanipulasi, mengubah, dan menghapus data. Dalam penyewaan bus, tidak ada nya sistem basis data penyewaan bus untuk menyimpan data - data penyewaan.

Masalah dalam administrasi yaitu didalam sistem pencatatan laporan keuangan dan penjualan tiket masih dilakukan secara manual dan tidak terintegrasi dengan baik, sehingga pendataannya tidak akurat. Selain itu terjadi kesulitan pembukuan keuangan karena laporan - laporan transaksi disimpan di file yang berbeda - beda. Aplikasi pemesanan tiket, penyewaan bus, dan administrasi ini dibuat untuk mempermudah customer atau penumpang dan penyewa bus dalam memesan tiket bus dan juga dalam melakukan penyewaan bus.

\section{METODE}

Metode penelitian yang dilakukan untuk penelitian ini adalah:

1. Inisiasi (initiation)

Tahap ini biasanya ditandai dengan pembuatan proposal proyek perangkat lunak. Pengembangan konsep sistem (system concept development) Mendefinisikan lingkup konsep termasuk dokumen lingkup sistem, analisis manfaat biaya, manajemen rencana, dan pembelajaran kemudahan sistem.

2. Perencanaan (planing)

Mengembangkan rencana manajemen proyek dan dokumen perencanaan lainnya. Analisis kebu- tuhan (requirements analysis) Menganalisis kebutuhan pemakai sistem perangkat lunak (user) dan mengembangkan kebutuhan user.

3. Desain (design)

Mentrasnformasikan kebutuhan detail menjadi kebutuhan yang sudah lengkap, dokumen desain sistem fokus pada bagaimana dapat memenuhi fungsi-fungsi yang dibutuhkan.

4. Pengembangan (development)

Mengkonversi desain ke sistem informasi yang lengkap termasuk bagaimana memperoleh dan melakukan instalasi lingkungan sistem yang dibutuhkan.

5. Integrasi dan pengujian (integration and test)

Mendemonstrasikan sistem perangkat lunak bahwa telah mem-enuhi kebutuhan yang dispesifikasikan pada dokumen kebutuhan fungsional.

6. Implementasi (implementation)

Pada persiapannya, implementasi perangkat lunak pada lingkungan produksi (lingkungan pada user) dan menjalankan resolusi dari permasalahan yang teridentifikasi dari fase integrasi dan pengujian.

7. Operasi dan pemeliharaan (operation and maintenance)

Mendepenelitiankan pekerjaan untuk mengoperasikan dan memelihara sistem informasi pada lingkungan produksi (lingkungan pada user), termasuk implementasi akhir dan masuk pada proses peninjauan.

8. Disposisi (disposition)

Mendepenelitiankan aktifitas akhir dari pengembangan system dan membangun data yang sebenarnya sesuai dengan aktifitas user.

\section{HASIL DAN PEMBAHASAN}

\section{Analisa Sistem}


JURTEKSI (Jurnal Teknologi dan Sistem Informasi)

Vol. V No. 1, Des 2018, hlm. 37 - 42

DOI: https://doi.org/10.33330/jurteksi.v5i1.295

Available online at http://jurnal.stmikroyal.ac.id/index.php/jurteksi
Analisis Sistem adalah penguraian dari suatu sistem informasi yang utuh kedalam bagian-bagian komponennya dengan maksud untuk mengidentifikasi dan mengevaluasi permasalahan, kesempatan dan hambatan-hambatan yang mungkin terjadi serta kebutuhan yang diharapkan sehingga dapat diusulkan perbaikan [3] .

Tahap analisa sistem dilakukan sebelum tahap perancangan sistem. Tahap analisa sistem merupakan tahap yang penting dalam perancangan suatu sistem, karena kesalahan didalam tahap ini akan menyebabkan kesalahan ditahap selanjutnya. Dalam tahap analisa sistem, kita analisa untuk menemukan kelemahan-kelemahan pada sistem yang sedang berjalan pada suatu organisasi atau perusahaan dengan tujuan agar sistem tersebut dapat diusulkan perbaikannya.

Berdasarkan peninjaun langsung ke PO.NPM, proses pemesanan tiket dilakukan secara manual. Pengolahan data penumpang juga dilakukan oleh pegawai dengan cara manual.

Untuk mengatasi masalah tersebut, maka dibuatlah suatu sistem yang dapat membantu penumpang melakukan pemesanan tiket secara online dan memudahkan pegawai dalam pengolahan data penumpang tersebut.

\section{Desain Sistem}

Setelah melakukan evaluasi terhadap sistem yang ada saat ini, maka penulis mencoba untuk mengusulkan suatu pengembangan terhadap sistem yang lama dengan tetap memperhatikan prosedur dan aliran sistem informasi yang ada dengan mengimplementasikan suatu bahasa pemograman berbasis web [4]. Dalam hal ini bahasa pemograman PHP dan database MySQL akan digunakan dalam mengolah sistem rservasi tiket penumpang di PO.NPM [5]. Dimana sistem baru ini dapat memberikan suatu manfaat yang signifikan dan sudah tentu dapat mempermudah kerja penumpang yang ingin melakukan pemesan tiket.

\section{Use Case Diagram}

Alur dari system pemesanan tiket berbasis web ini dapat di gambarkan seperti diagram flow di bawah ini :

\begin{tabular}{|c|c|c|}
\hline & Aktoor & Depenelitian \\
\hline 1 & Admin & $\begin{array}{l}\text { Admin disini adalah yang } \\
\text { bertugas dan memiliki hak } \\
\text { akses dalam melakukan } \\
\text { keseluruhan operasi } \\
\text { megenai kontrol data } \\
\text { sistem registrasi ulang } \\
\text { penumpang baru. }\end{array}$ \\
\hline 2 & User & $\begin{array}{lr}\text { User adalah } & \text { calon } \\
\text { penumpang } & \text { yang } \\
\text { melakukan } & \text { pemesanan } \\
\text { tiket online. } & \end{array}$ \\
\hline 3 & $\begin{array}{l}\text { Karyaw } \\
\text { an }\end{array}$ & $\begin{array}{l}\text { Bertugas untuk } \\
\text { mengentrikan harga tiket } \\
\text { dan tujuan keberangkatam }\end{array}$ \\
\hline
\end{tabular}

Tabel 1.Depenelitian Aktor Pada Usecase Diagram

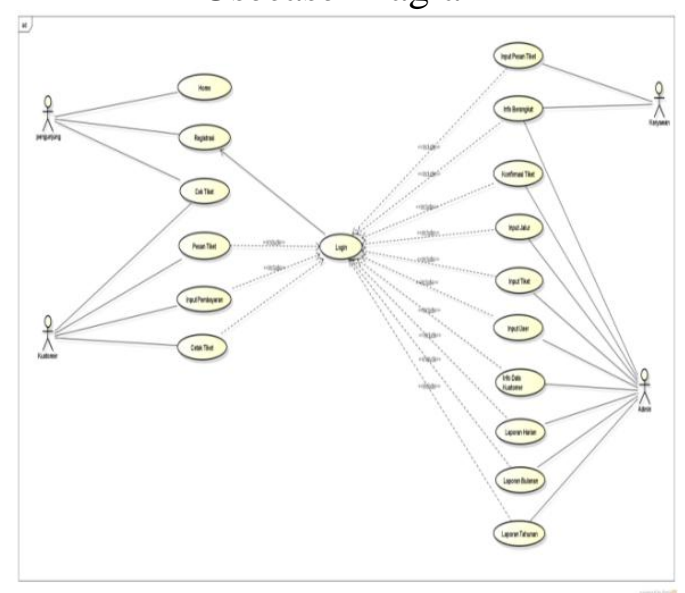

Gambar 1. Use Case Diagram

\section{Class Diagram}


DOI: https://doi.org/10.33330/jurteksi.v5i1.295

Available online at http://jurnal.stmikroyal.ac.id/index.php/jurteksi

Class diagram merupakan himpunan dari objek-objek yang memiliki struktur sama, serta memilki perilaku dan relasi yang sama pula [6]. Kelas mempresentasikan suatu konsep diskret di dalam aplikasi yang dimodelkan. Pada setiap class terdapat attribute dan operation. Diagram class dirancang berdasarkan pada perancangan database. Perancangan class seperti ini disebut dengan class entity.

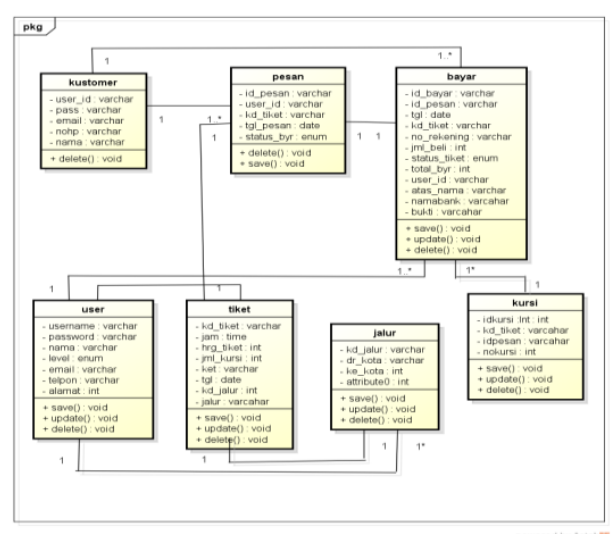

Gambar 2. Class Diagram.

\section{Sequence Diagram}

Sequence diagram menjelaskan urutan proses yang dilakukan dalam sistem untuk mencapai tujuan dari use case : interaksi yang terjadi antar class, operasi apa saja yang terlibat, urutan antar operasi, dan informasi yang diperlukan oleh masing-masing operasi [6].

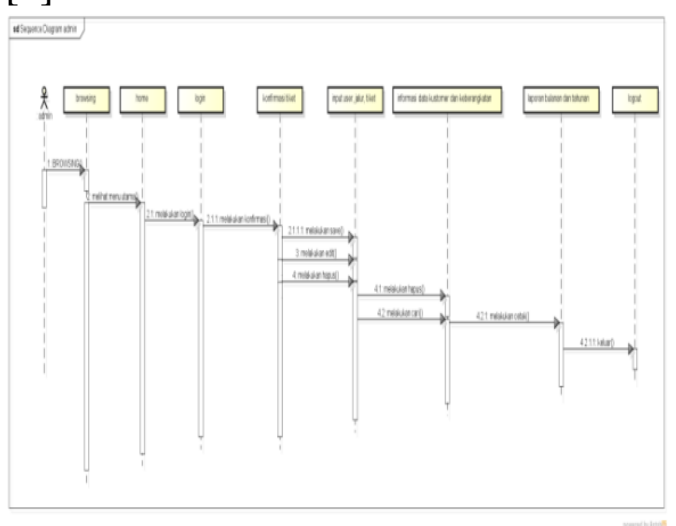

Gambar 3. Sequence Diagram Admin.

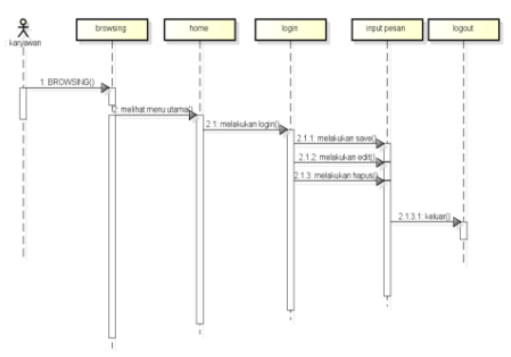

Gambar 4. Sequence Diagram karyawan.

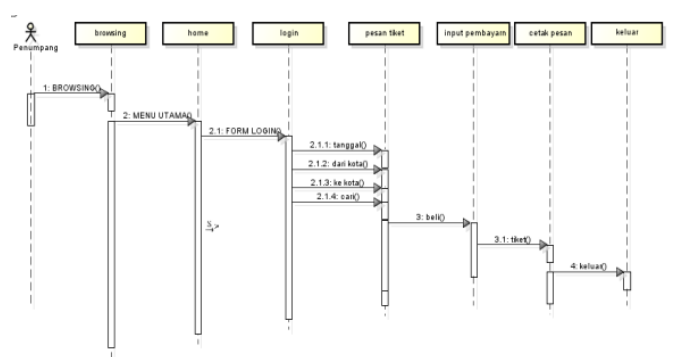

Gambar 5. Sequence Diagram

Kustomer.

\section{Implementasi Sistem}

Komputer digunakan sebagai sebuah alat bantu dalam kehidupan sehari-hari, salah satunya adalah untuk mengimplementasikan program aplikasi yang telah dirancang, yang mana untuk mengoperasikan komputer itu sendiri memerlukan tiga buah komponen pendukung seperti hardware, software, dan brainware. Untuk lebih jelasnya dapat dilihat fungsi dari masing-masing komponen tersebut sebagai berikut:

\section{Halaman Form Menu Utama}

a. Halaman Menu Utama 
JURTEKSI (Jurnal Teknologi dan Sistem Informasi)

Vol. V No. 1, Des 2018, hlm. 37 - 42

DOI: https://doi.org/10.33330/jurteksi.v5i1.295

Available online at http://jurnal.stmikroyal.ac.id/index.php/jurteksi

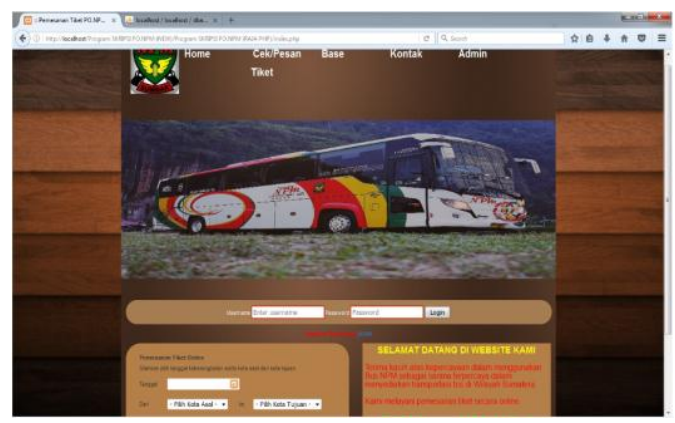

Gambar 6. Halaman Menu Utama.

Form menu utama adalah antar muka (interface) yang digunakan sebagai form induk / form utama. Form utama ini akan selalu ditampilkan saat program dijalankan. Halaman ini merupakan halaman menu utama pada website. Pada halaman ini tersedia menu-menu yang dapat diakses dengan mengklik tombol menu tersebut.

\section{b. Halaman Entry harga tiket}

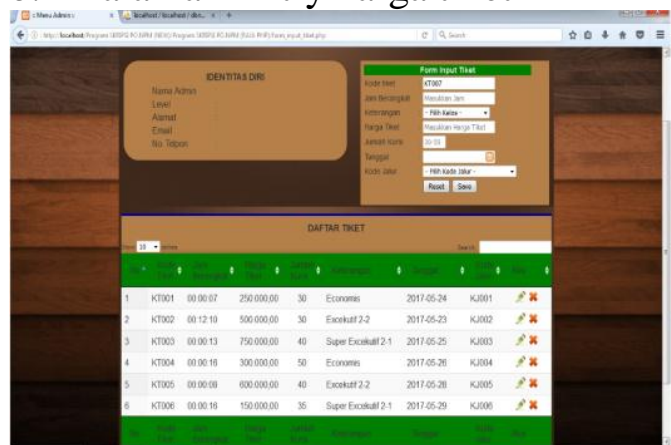

Gambar 7. Halaman Entry Harga Tiket

Halaman ini merupakan halaman untuk admin melakukan entri data harga tiket.

c. Halaman Pemesanan Tiket

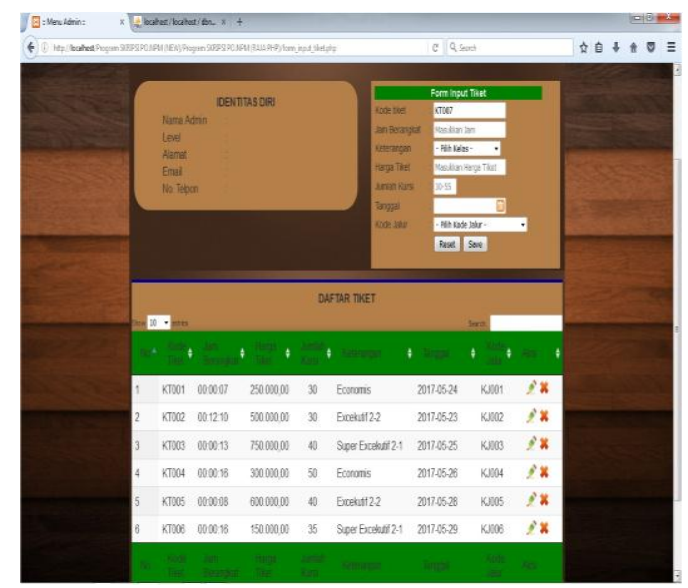

Gambar 8. Halaman Pemesanan Tiket.

Halaman pemesanan tiket merupaka halaman yang dapat membantu penumpang dalam memilih hari,tujuan dan jam keberangkatan penumpang tersebut.

d. Halaman Entry Daftar Kostumer

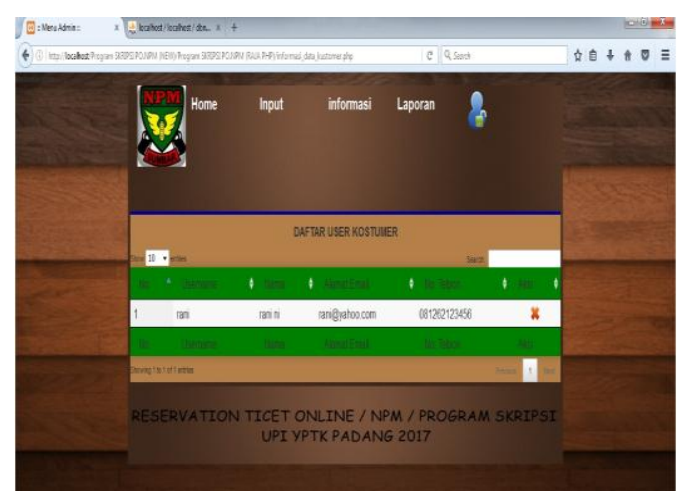

Gambar 9. Halaman Entry Daftar Kostumer.

Halaman ini merupakan halaman untuk admin melakukan entry data kostumer Halaman ini hanya bisa di akses oleh admin.

e. Halaman Form Upload Bukti Pembelian Tiket 
DOI: https://doi.org/10.33330/jurteksi.v5i1.295

Available online at http://jurnal.stmikroyal.ac.id/index.php/jurteksi

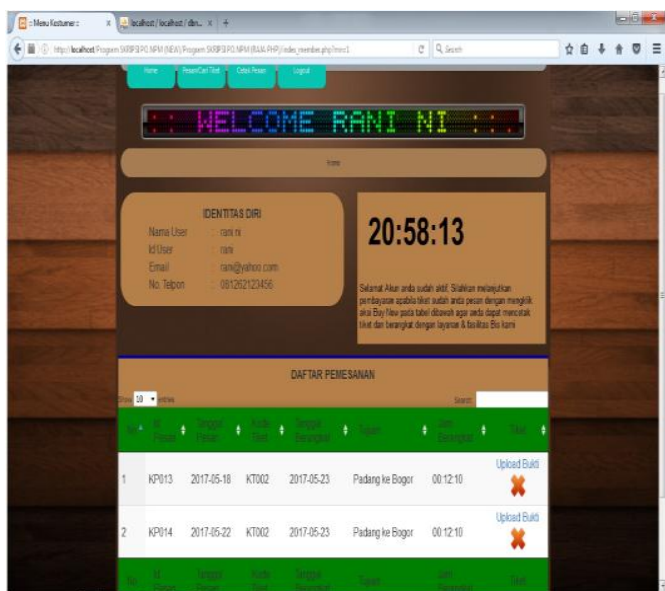

Gambar 10. Halaman Form Upload Bukti Pembelian Tiket.

Halaman from upload bukti pembelian tiket ini hanya dapat dilakukan setelah menklik upload bukti dan barulah keluar tampilan form upload bukti seperti di atas dan kostumer langsung menekan tombolbrowse dan setelah itu baru tekan tombol save.

f. Halaman Form Upload Bukti Pembelian Tiket

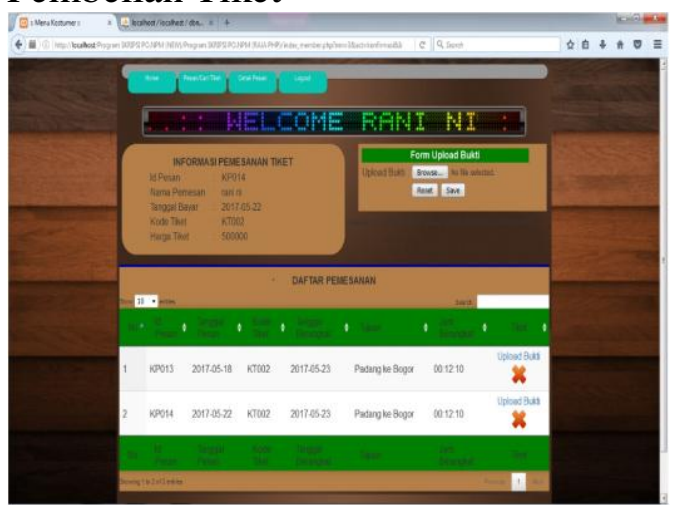

Gambar 11. Halaman Form Upload Bukti Pembelian Tiket.

Halaman from upload bukti pembelian tiket ini hanya dapat dilakukan setelah menklik upload bukti dan barulah keluar tampilan form upload bukti seperti di atas dan kustumer langsung menekan tombol browse dan setelah itu baru tekan tombol save.

\section{g. Halaman Cetak Tiket Pemesanan} Halaman cetak pemesanan tiket ini keluar / tampil setelah kustumer ingin cetak bukti pemesanan, dan juga sebagai bukti kustumer telah membayar pemesanan tiket tersebut.

\begin{tabular}{|c|c|}
\hline जer? & 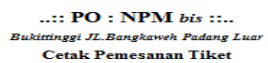 \\
\hline No. Transaksi & |||||||||||||||||||||||||||||||||||||| \\
\hline Nama Di Rekening & : rani \\
\hline No. Rekcning & $=1234$ \\
\hline Tgl Pesan & $=2017-05-29$ \\
\hline Username & $=\mathbf{r a n i}$ \\
\hline Tujuan & Bukittinggi ke Jakarta \\
\hline Tgl Berangkat & $2017-05-31$ \\
\hline Jam & $=00: 00: 16$ \\
\hline Kelas Bis & : Super Excekutif 2-1 \\
\hline Harga Tiket & $R_{p} 400.000_{2} 00$ \\
\hline Jumlah Pesan & $=2$ \\
\hline Nomor Kursi & $=9,10=$ \\
\hline Total Bayar & Rp. $800.000,00$ \\
\hline
\end{tabular}

Gambar 12. Halaman Cetak Tiket Pemesanan.

\section{SIMPULAN}

Dari hasil penelitian dapat disimpulkan

1. Aplikasi system pemesanan tiket dapat di gunakan sebagai sarana penyampaian informasi tentang BUS, terminal, keberangkatan dan lain sebagainya.

2. Aplikasi system pemesanan tiket ini dapat membantu mempermudah user atau konsumen dalam melakukan transaksi pemesanan tiket.

3. Aplikasi sistem pemesanan tiket disini dapat dijalankan dengan syarat lebih dahulu menjadi anggota dengan cara daftar pada link daftar di web program ini.

4. Dalam pembuatan aplikasi program tersebut penulis menggunakan Bahasa Pemrograman PHP dan database MySQL, sehingga dapat terlihat informasi yang dihasilkan 
DOI: https://doi.org/10.33330/jurteksi.v5i1.295

Available online at http://jurnal.stmikroyal.ac.id/index.php/jurteksi

lebih cepat .

\section{DAFTAR PUSTAKA}

[1] Kakiyai,Thomas J (2004), "Dasar Teori Untuk Kehidupan Nyata " ,Yogyakarta,amdi

[2] Yakub (2012), "Pengantar Sistem Informasi ".Graha Ilmu, Yogyakarta.

[3] Gunawan, Firman. (2001), “Web Based Learning Proses Pembelajaran Dengan Manfaat Teknologi Informasi “,Malang

[4] Kerja Sama Team, 2008, "PHP \& MYSQL Untuk Pemula” .Maadiun: Penerbit Andi.

[5] Kerja Sama Team, 2011, "Dreamweaver CS5 PHP MYSQL untuk Pemula". MADCOMS MADIUN: Andi Yogyakarta.

[6] Rosa A.S \& M. Shalahudin (2011 -2014), "Rekayasa Perangkat Lunak dan Berorientasi Objek ", informatika, Bandung. 